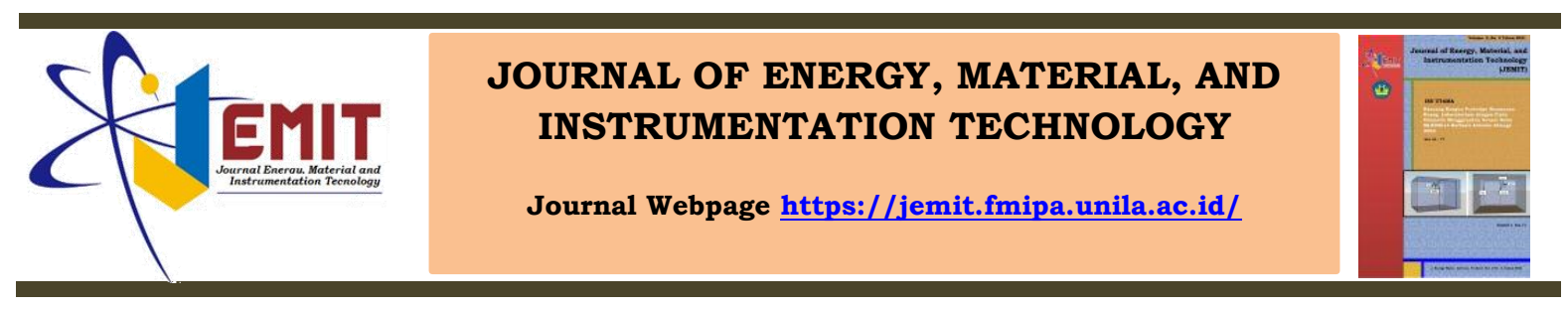

\title{
Analisis Jembatan Garam Campuran Alumina dan Kalsium Karbonat pada Karakteristik Elektrik Pembangkit Listrik Sel Galvanis dengan Elektrolit Air Laut
}

\author{
Gurum Ahmad Pauzi*, Syaiful Anwar, Amir Supriyanto, dan Sri Wahyu Suciyati \\ Jurusan Fisika, Universitas Lampung, Bandar Lampung, Indonesia, 35141
}

\begin{tabular}{|c|c|}
\hline Article Information & Abstract \\
\hline $\begin{array}{l}\text { Article history: } \\
\text { Received Oktober } 26^{\text {th }}, 2021 \\
\text { Received in revised form } \\
\text { November } 16^{\text {th }}, 2021 \\
\text { Accepted November } 18^{\text {th }}, \\
2021\end{array}$ & $\begin{array}{l}\text { In this research was conducted to analyze the effect of variations in the } \\
\text { concentration of the salt bridge mixture on the electrical characteristics of } 5 \text { series } \\
\text { galvanized cells using Cu(Ag)-Zn electrodes with a load of } 20 \text { LEDs. Variation of } \\
\text { concentration of salt bridge mixture using } 0,1 \text { and } 1 \text { mole of alumina, O, } 1 \text { dan } 1 \\
\text { mole of calcium carbonate in cement using seawater as solvent. Monitoring the } \\
\text { voltage and current in the galvanic cell uses the INA2 } 19 \text { sensor, while the light } \\
\text { intensity monitoring uses the BH1750 sensor in real-time. The results showed } \\
\text { that the greater the concentration of alumina in the salt bridge, the greater the } \\
\text { value of the resulting stress. The value of the resistance in the galvanic cell will } \\
\text { be smaller if the concentration of the calcium carbonate salt bridge has a small } \\
\text { value. }\end{array}$ \\
\hline Informasi Artikel & Abstrak \\
\hline $\begin{array}{l}\text { Proses artikel: } \\
\text { Diterima } 26 \text { Oktober } 2021 \\
\text { Diterima dan direvisi dari } \\
16 \text { November } 2021 \\
\text { Diterima } 18 \text { November } 2021\end{array}$ & $\begin{array}{l}\text { Penelitian ini dilakukan untuk menganalisis pengaruh variasi konsentrasi } \\
\text { campuran jembatan garam terhadap karakteristik elektrik } 5 \text { buah sel galvanis } \\
\text { seri menggunakan elektroda Cu(Ag)-Zn dengan beban } 20 \text { LED. Variasi } \\
\text { konsentrasi campuran jembatan garam menggunakan alumina } 0,1 \text { dan } 1 \text { mol, } \\
\text { kalsium karbonat } 0,1 \text { dan } 1 \mathrm{~mol} \text { pada semen dengan menggunakan air laut } \\
\text { sebagai pelarut. Monitoring tegangan dan arus pada sel galvanis menggunakan } \\
\text { sensor INA219 sedangkan monitoring intensitas cahaya menggunakan sensor } \\
\text { BH1750 secara real-time. Hasil penelitian menunjukkan bahwa semakin besar } \\
\text { konsentrasi alumina pada jembatan garam akan semakin besar nilai tegangan } \\
\text { yang dihasilkan. Nilai hambatan dalam sel galvanis akan semakin kecil apabila } \\
\text { konsentrasi jembatan garam kalsium karbonat memiliki nilai kecil. }\end{array}$ \\
\hline
\end{tabular}

\section{Pendahuluan}

Energi termasuk kebutuhan dasar manusia yang terus meningkat sejalan dengan tingkat pertumbuhan penduduk (Kholiq, 2015). Salah satunya energi listrik, energi listrik digunakan dalam kehidupan masyarakat berkapasitas rendah sampai ke dunia industri dalam jumlah yang sangat besar (Pratisto, 2014). Berdasarkan data Kementerian Energi dan Sumber Daya Mineral tahun 2018, pembangkit EBT pada tahun 2017 mampu menghasilkan energi listrik sebesar $12,52 \%$. Pencapaian tersebut dihasilkan oleh sektor EBT Pembangkit Listrik Tenaga Air (PLTA) sebesar 7,27\%, Pembangkit Listrik Tenaga Panas (PLTP) sebesar 5\% dan sektor EBT lainnya sebesar $0,25 \%$. Berdasarkan data tersebut, hingga saat ini penyediaan energi listrik di Indonesia belum merata serta belum dimanfaatkannya potensi energi terbarukan secara maksimal salah satunya laut sebagai sumber energi listrik alternatif (Pauzi dkk, 2016).

Salah satu energi alternatif yang dapat dimanfaatkan adalah air laut. Air laut mengandung unsur Natrium Klorida $(\mathrm{NaCl})$ yang tinggi dan $\mathrm{H}_{2} \mathrm{O}$. Air laut dapat berpotensi menghasilkan energi listrik dengan memanfaatkan proses elektrokimia (Prastuti, 2017). Elektrokimia merupakan perubahan energi kimia menjadi energi listrik akibat adanya dua buah elektroda dan elektrolit sebagai penghantar elektron (Votava, 2013). Untuk menghasilkan energi listrik, jenis sel elektrokimia yang digunakan adalah sel volta. Sel volta suatu elektrolit air laut diberikan dua buah logam sebagai elektroda yang terhubung satu sama lain dan memiliki beda potensial yang menghasilkan energi listrik.

* Corresponding author

E-mail addres: gurum@fmipa.unila.ac.id 
Pemanfaatan sel volta merupakan hasil terapan sel elektrokimia untuk menghasilkan teknologi energi alternatif. Sel volta pada satu sel menyebabkan transfer elektron terjadi secara cepat menyebabkan korosi karena perbedaan potensial yang berada dalam suatu lingkungan elektrolit (Wibowo, 2016). Jika sel air laut dipisahkan maka tidak terjadi aliran listrik, sehingga pada sel elektrokimia diperlukan jembatan garam supaya ion-ion dalam larutan seimbang dan terjadi perubahan kimia menjadi perubahan listrik. jembatan garam memiliki fungsi untuk menyetarakan kation dan anion dalam larutan. Adapun syarat jembatan garam yaitu bisa dilewati ion dan hanya sedikit melewatkan pelarut (Arizal dkk, 2017). Hasil penelitian yang telah dilakukan oleh Akbar dkk (2017) membuat sel volta dengan bantuan jembatan garam menggunakan bakteri sebagai katalis untuk menghasilkan arus listrik dan Haq dkk (2018) membuat sel volta dengan bantuan jembatan garam untuk aplikasi pembangkit listrik menggunakan energi garam sebagai elektrolit. Hasil penelitian tersebut menunjukkan bahwa adanya jembatan garam pada sel volta menyebabkan aliran elektron dalam larutan seimbang sehingga menghasilkan arus listrik.

Penelitian tentang sel volta dengan bantuan jembatan garam $\mathrm{NaCl}$ dan $\mathrm{KCl}$ menggunakan pasangan elektroda $\mathrm{Cu}(\mathrm{Ag})-\mathrm{Zn}$, dimana pemanfaatan Ag dilakukan untuk mengurangi korosi pada permukaan $\mathrm{Cu}$. Logam Ag melapisi elektroda $\mathrm{Cu}$ untuk dilindungi dengan cara proses elektroplating (Pauzi dkk, 2018a). Hasil penelitian menunjukkan bahwa $\mathrm{Cu}(\mathrm{Ag})$ lebih tahan terhadap korosi oleh air laut dengan laju korosi 5 kali lebih rendah dibandingkan $\mathrm{Cu}$. Namun, semakin lama penggunaan elektrolit air laut dengan beban yang diberikan dapat menyebabkan korosi pada elektroda sehingga energi yang dihasilkan semakin lama akan semakin menurun (Crus dkk, 2017). Pasangan elektroda $\mathrm{Cu}(\mathrm{Ag})-\mathrm{Zn}$ dengan penambahan jembatan garam $\mathrm{NaCl}$ dan $\mathrm{KCl}$ menghasilkan nilai karakteristik elektrik yang lebih besar dan stabil dibandingkan Cu-Zn dengan jembatan garam (Pauzi dkk, 2018b). Akan tetapi, nilai close circuit voltage $(C C V)$ yang dibutuhkan sebagai sumber penerangan pada penelitian tersebut masih besar dan intensitas cahaya yang dihasilkan belum memperoleh hasil yang maksimal. Sehingga, dilakukan pengembangan riset lebih lanjut merancang sel volta dengan bantuan jembatan garam yang lebih sederhana menggunakan jembatan garam $\mathrm{Al}_{2} \mathrm{O}_{3}$ (alumina), $\mathrm{CaCO}_{3}$ (kalsium karbonat) dan semen dengan pasangan elektroda $\mathrm{Cu}(\mathrm{Ag})-\mathrm{Zn}$.

\section{Metode Penelitian}

Alat yang digunakan dalam penelitian ini antara lain: media elektrolit air laut dari bahan acrylic, sel volta terbuat dari bahan acrylic yang tebalnya $3 \mathrm{~mm}$ dengan ukuran 9x4x12 cm, galon, filter air kaut, logam $\mathrm{Zn}$ ukuran 4x7x0,002 cm, LED $3 \mathrm{~mm} 20 \mathrm{~mA}$ sebanyak 20 buah, solder dan PC (personal computer). Media elektronika yaitu IDE Arduino, Arduino nano, sistem monitoring dengan sensor INA219, sensor BH1750 dan power supply. Bahan yang digunakan dalam penelitian ini antara lain: air laut $200 \mathrm{ml}$ sebagai bahan utama yang digunakan penelitian ini. Bahan elektroplating antara lain: batang karbon, kabel serabut $\mathrm{Cu}$ ukuran 2,5 $\mathrm{mm}$, Ag sebagai pelapis serabut $\mathrm{Cu}$, aquades, alkohol $70 \%$, larutan $\mathrm{HNO}_{3}$, larutan $\mathrm{AgNO}_{3}$. Bahan jembatan garam yaitu alumina 0,1 mol dan $1 \mathrm{~mol}$, kalsium karbonat $0,1 \mathrm{~mol}$ dan $1 \mathrm{~mol}$, semen baturaja, dan air laut.

Penelitian ini dilakukan dalam beberapa tahapan yaitu proses elektroplating Ag pada $\mathrm{Cu}$, pembuatan jembatan garam, perancangan dan pembuatan sistem sel volta, perancangan sistem monitoring serta pengujian alat.

\subsection{Proses Elektroplating Ag pada Cu}

Proses elektroplating menggunakan batang karbon sebagai anoda dan serabut $\mathrm{Cu}$ ukuran diameter $2,5 \mathrm{~mm}$ dan panjang $120 \mathrm{~cm}$ sebagai katoda. Proses elektroplating Ag pada Cu dengan menggunakan larutan sepuh perak $\left(\mathrm{AgNO}_{3}\right)$ 0,02 $\mathrm{M}$ sebanyak $300 \mathrm{ml}$ sebagai larutan elektrolitnya. Sebelum elektroplating serabut $\mathrm{Cu}$ dibersihkan menggunakan larutan $\mathrm{HNO}_{3} \quad 1 \%$ untuk mengurangi kandungan lemak yang menempel pada $\mathrm{Cu}$. Kemudian $\mathrm{Cu}$ dibersihkan kembali menggunakan etanol 96\% untuk menghilangkan kandungan $\mathrm{HNO}_{3}$ yang masih menempel pada $\mathrm{Cu}$. Selanjutnya, elektroplating dilakukan dengan tegangan 2 volt selama 5 menit.

\subsection{Pembuatan Jembatan Garam}

Pada tahap ini dilakukan proses pembuatan jembatan garam campuran alumina + kalsium karbonat $+\mathrm{NaCl}+$ semen. Langkah awal membuat jembatan garam yakni mencampurkan 102 gram untuk alumina 1 mol, 100 gram untuk kalsium karbonat $1 \mathrm{~mol}$, 58,5 gram untuk $\mathrm{NaCl} 1 \mathrm{~mol}$ dan 70 gram semen, kemudian diaduk hingga bahan tersebut tercampur. Kemudian campuran tersebut dicetak langsung didalam sel untuk menghindari kebocoran, lalu keringkan dan tunggu hingga mengeras. Tujuan pembuatan jembatan garam ini untuk menjaga kenetralan muatan listrik pada larutan.

\subsection{Perancangan dan Pembuatan Sistem Sel Volta}

Sistem sel volta memiliki 5 sel yang terbuat dari bahan acrylic yang tebalnya $3 \mathrm{~mm}$ yang dihubungkan secara seri. Setiap sel berisi sepasang elektroda $\mathrm{Cu}(\mathrm{Ag})-\mathrm{Zn}$ dan sebuah jembatan garam. Elektrolit yang digunakan pada sel volta ini adalah air laut. Setiap sel berisi air laut pada kompartemen sebanyak $\pm 200 \mathrm{ml}$. desain sel volta pada penelitian ini dapat dilihat pada Gambar 1. 
Pauzi GA, Anwar S, Supriyanto A, dan Suciyati SW, 2021, Analisis Jembatan Garam Campuran Alumina dan Kalsium Karbonat pada Karakteristik Elektrik Pembangkit Listrik Sel Galvanis dengan Elektrolit Air Laut, Journal of Energy, Material, and Instrumentation Technology, Vol. 2, No. 4, 2021

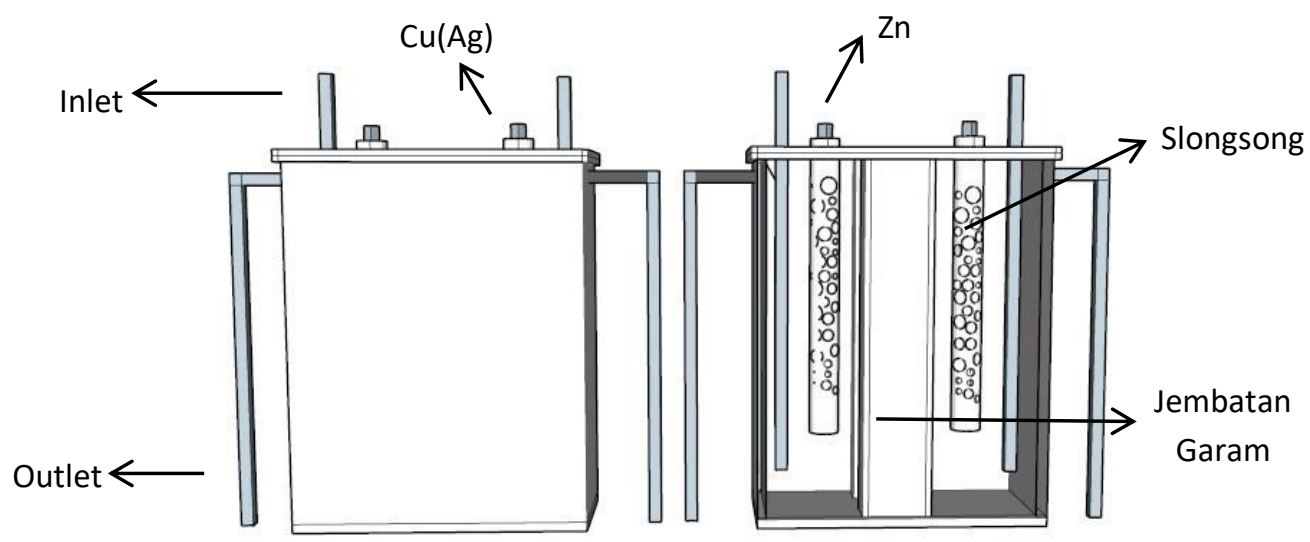

Gambar 1. Desain sel volta

\subsection{Pembuatan Sistem Monitoring}

Perancangan sistem monitoring dengan parameter pengukuran yang akan dilakukan pada sel volta air laut meliputi open circuit voltage (OCV) (volt), close circuit voltage (CCV) (volt), arus (I) (mA), dan intensitas cahaya (Lux). OCV adalah perbedaan potensial listrik antara dua terminal perangkat ketika tidak ada beban yang terhubung. Sebaliknya, CCV adalah perbedaan potensial listrik antara dua terminal perangkat ketika ada beban yang terhubung.

Secara umum, rancangan sistem yang akan dibangun meliputi otomatisasi, pendeteksian parameter, pemroses dan penyimpanan data. Pada tahap otomatisasi, output sel volta yang terhubung dengan beban akan terintegrasi relay. Relay berfungsi sebagai saklar pada beban agar sistem dapat mengukur OCV dan CCV secara otomatis. Sementara itu, pada tahap pendeteksian parameter, sensor akan mendeteksi parameter fisis dan mengubahnya menjadi besaran listrik (sinyal analog). Kemudian sinyal analog akan dikonversi menjadi sinyal digital menggunakan pemroses Arduino. Selain itu, RTC (Real Time Clock) sebagai sumber waktu akan memberikan keterangan yang meliputi waktu saat pengukuran berlangsung dengan nilai digital yang diperoleh sensor. Nilai digital dan keterangan waktu pengukuran tersebut kemudian akan disimpan pada data logger menggunakan $S D$ Card. Desain rangkaian sistem monitoring ditunjukkan pada Gambar 2.

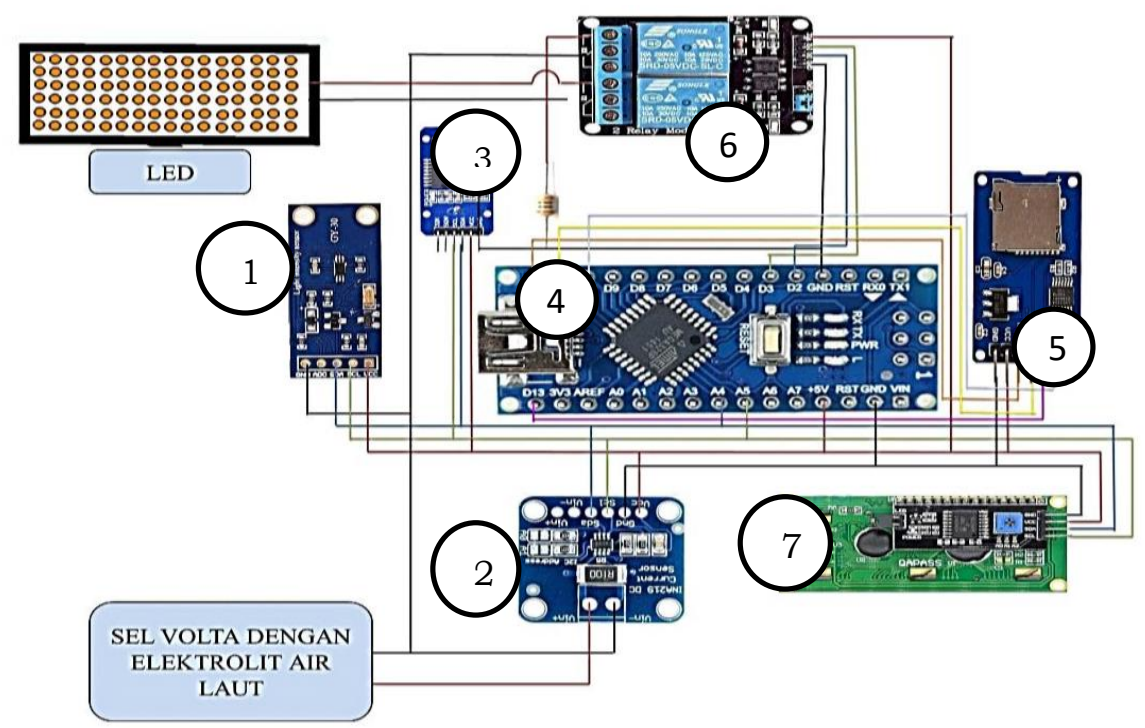

Gambar 2. Desain rangkaian sistem monitoring

Keterangan:

1. Sensor BH1750

2. Sensor INA219

3. RTC (Real Time Clock) DS3231

4. Arduino Nano

5. Micro SD Card Adapter (Data Logger)

6. Relay

7. LCD 


\subsection{Pengujian Alat}

Pengujian alat dilakukan dengan menghubungkan output elektroda $\mathrm{Cu}(\mathrm{Ag})-\mathrm{Zn}$ ke input monitoring yang telah terhubung ke beban (20 LED). Analisis energi listrik dilakukan dengan proses pengambilan data dengan sistem monitoring berupa nilai $\mathrm{OCV}, \mathrm{CCV}$, dan arus serta dilakukan perhitungan hambatan dalam $\left(\mathrm{R}_{\text {in }}\right)(\mathrm{kOhm})$ menggunakan persamaan 1 dan dilakukan perhitungan daya yang dihasilkan menggunakan persamaan 2 . Pengambilan data dilakukan setiap 1 jam sekali selama 72 jam.

$$
\begin{gathered}
R_{\text {in }}=\frac{O C V-C C V}{I} \\
P=C C V . I
\end{gathered}
$$

Pada persamaan $1, R_{\text {in }}=$ hambatan dalam $(\Omega), \mathrm{OCV}=$ open circuit voltage (volt), CCV $=$ close circuit voltage (volt) dan $\mathrm{I}=$ kuat arus $(\mathrm{mA})$. Pada persamaan $2, P=$ daya (watt), $\mathrm{CCV}=$ close circuit voltage (volt) dan $\mathrm{I}=$ kuat arus $(\mathrm{mA})$.

\section{Hasil Dan Pembahasan}

\subsection{Open Circuit Voltage (OCV) dan Close Circuit Voltage (CCV)}

Proses pengambilan data dalam penelitian ini dilakukan setiap 1 jam selama 72 jam dengan hasil pengukuran OCV dan CCV. Variasi konsentrasi jembatan garam yang digunakan yaitu alumina $1 \mathrm{~mol}+$ kalsium karbonat $1 \mathrm{~mol}$ jembatan garam pertama; jembatan garam kedua alumina 0,1 mol + kalsium karbonat 0,1 mol; jembatan garam ketiga alumina $1 \mathrm{~mol}+$ kalsium karbonat 0,1 mol; dan jembatan garam keempat alumina 0,1 mol + kalsium karbonat 1 mol. Adapun data OCV dari pasangan elektroda $\mathrm{Cu}(\mathrm{Ag})-\mathrm{Zn}$ dengan variasi konsentrasi jembatan garam setiap 1 jam selama 72 jam pada 5 sel volta ditampilkan seperti pada Gambar 3.

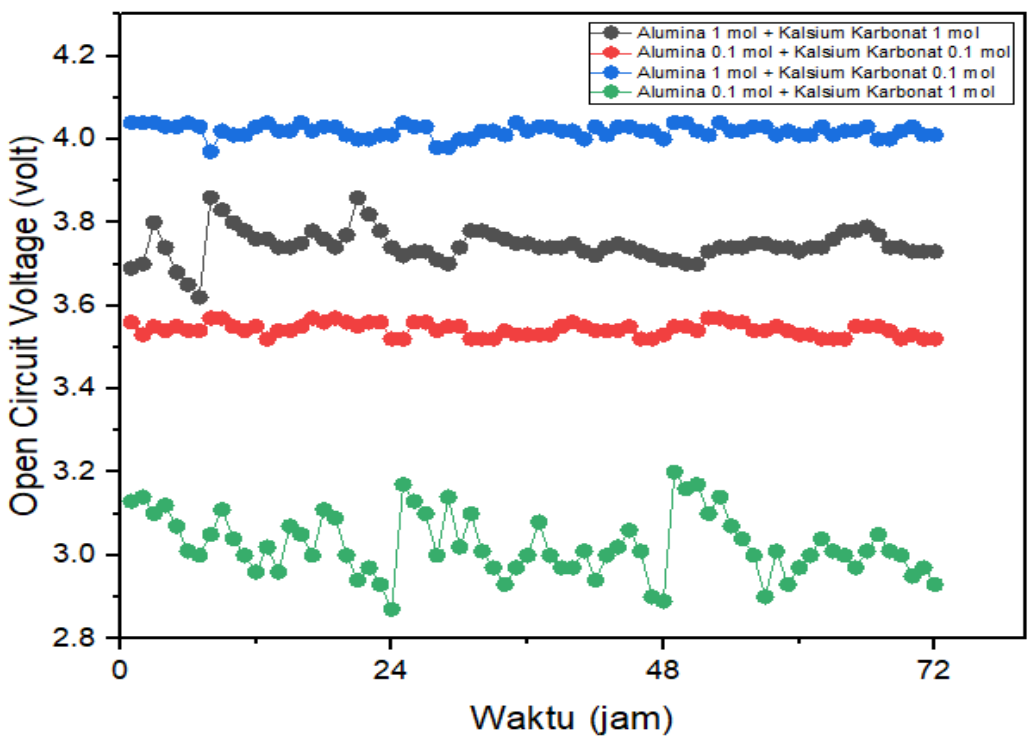

Gambar 3. Grafik pengukuran OCV

Gambar 3 menunjukkan grafik pengukuran OCV. Variasi konsentrasi jembatan garam pertama mengalami ketidakstabilan. Nilai OCV pada satu jam pertama yang dihasilkan sebesar 3,69 volt. Sedangkan nilai OCV pada jam ke-72 yang dihasilkan sebesar 3,73 volt. Variasi konsentrasi jembatan garam kedua cenderung stabil, namun nilai OCV yang dihasilkan lebih kecil dibandingkan dengan jembatan garam pertama. Hal ini disebabkan perbedaan konsentrasi jembatan garam pada alumina. Hal ini sesuai berdasarkan penelitian sebelumnya, bahwa semakin besar konsentrasi alumina yang digunakan maka semakin besar nilai OCV yang diperoleh (Parkash, 2016). Pada variasi konsentrasi jembatan garam ketiga cenderung stabil dan memiliki nilai OCV yang lebih tinggi dibandingkan dengan variasi konsentrasi jembatan garam lain. Hal ini terjadi karena konsentrasi jembatan garam alumina bernilai besar dan kalsium karbonat bernilai kecil. Semakin kecil konsentrasi kalsium karbonat, maka semakin kecil nilai hambatan dalam (Khormali dkk, 2017). Pada variasi konsentrasi jembatan garam keempat cenderung tidak stabil dan memiliki nilai OCV yang lebih kecil dibandingkan dengan variasi konsentrasi jembatan garam lain. OCV bernilai kecil terjadi karena variasi jembatan garam alumina bernilai kecil dan variasi jembatan garam kalsium karbonat bernilai besar. OCV tertinggi diperoleh sebesar 3,20 volt pada jam ke-49. Sedangkan OCV terendah diperoleh pada jam ke-24 sebesar 2,87 volt. 
Pauzi GA, Anwar S, Supriyanto A, dan Suciyati SW, 2021, Analisis Jembatan Garam Campuran Alumina dan Kalsium Karbonat pada Karakteristik Elektrik Pembangkit Listrik Sel Galvanis dengan Elektrolit Air Laut, Journal of Energy, Material, and Instrumentation Technology, Vol. 2, No. 4, 2021

Tabel 1. Hasil pengukuran OCV

\begin{tabular}{cccc}
\hline Alumina $(\mathrm{mol})$ & Kalsium karbonat $(\mathrm{mol})$ & Rata-Rata $(\mathrm{volt})$ & Keterangan \\
\hline 1 & 1 & 3,745 & Tidak Stabil \\
0,1 & 0,1 & 3,542 & Stabil \\
1 & 0,1 & 4,019 & Stabil \\
0,1 & 1 & 3,024 & Tidak Stabil \\
\hline
\end{tabular}

Tabel 1 menunjukkan hasil pengukuran OCV. Berdasarkan hasil pengukuran, konsentrasi jembatan garam pertama memiliki nilai elektrik rata-rata yang lebih besar dengan konsentrasi jembatan garam yang lainnya. Hasil pengukuran tersebut menunjukkan nilai rata-rata sebesar 3,745 volt.

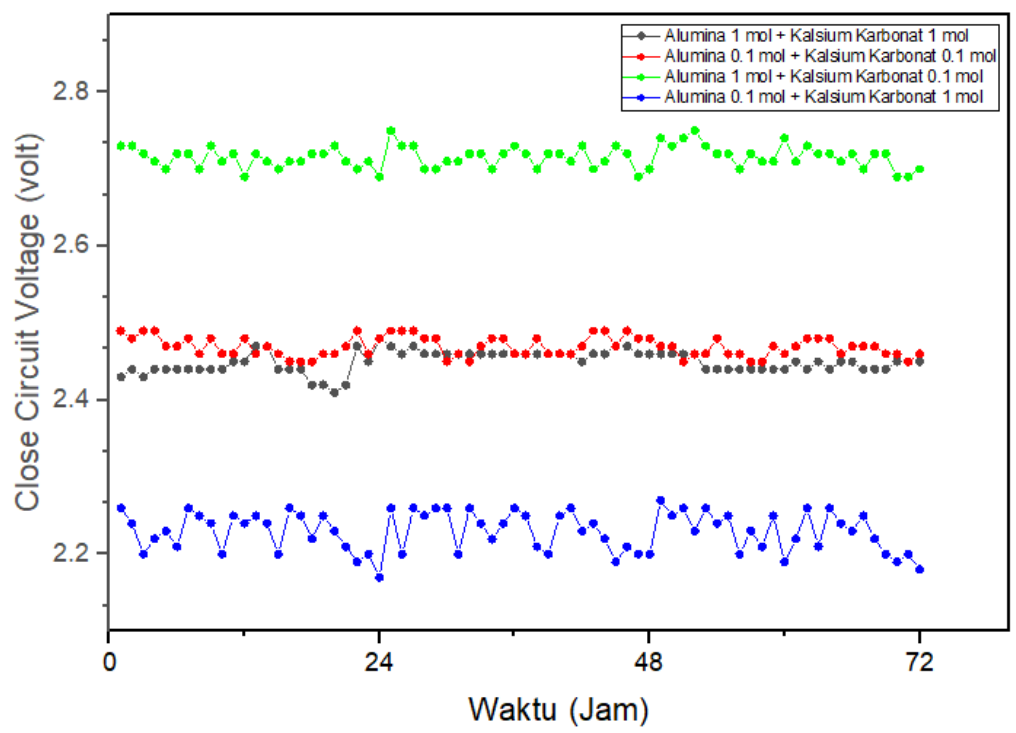

Gambar 4. Grafik pengukuran CCV

Grafik pada Gambar 4 menunjukkan hasil pengukuran CCV. nilai CCV pada satu jam pertama yang dihasilkan jembatan garam pertama sebesar 2,43 volt. Sedangkan nilai CCV pada jam ke-72 adalah 2,45 volt. Kestabilan nilai CCV yang dihasilkan terjadi pada jam ke-4 sampai jam ke-10, jam ke-28 sampai jam ke-41, dan jam ke-53 sampai jam ke-60. Variasi konsentrasi jembatan garam pertama hasil pengukuran CCV cukup stabil. Nilai CCV tertinggi sebesar 2,40 volt, sedangkan nilai CCV terendah sebesar 2,45 volt. Penurunan nilai CCV jembatan garam ini tidak terlalu besar yaitu sebesar 0,04 volt. Variasi konsentrasi jembatan garam memiliki nilai CCV yang lebih besar dibandingkan jembatan garam lain. Nilai CCV terendah sebesar 2,69 volt pada jam ke-12, 24, 47, 70 dan 71 . Variasi konsentrasi jembatan garam keempat nilai pengukuran CCV cukup tidak stabil. Nilai CCV pada satu jam pertama adalah 2,26 volt dan pada jam ke-72 adalah 2,18 volt dengan penurunan nilai CCV sebesar 0,1 volt.

Tabel 2. Hasil pengukuran CCV

\begin{tabular}{cccc}
\hline Alumina $(\mathrm{mol})$ & Kalsium karbonat $(\mathrm{mol})$ & Rata-Rata (volt) & Keterangan \\
\hline 1 & 1 & 2,449 & Stabil \\
0,1 & 0,1 & 2,469 & Stabil \\
1 & 0,1 & 2,715 & Stabil \\
0,1 & 1 & 2,229 & Tidak Stabil \\
\hline
\end{tabular}

Tabel 2 menunjukkan hasil pengukuran CCV. berdasarkan hasil pengukuran CCV menunjukkan bahwa konsentrasi jembatan garam ketiga memiliki nilai elektrik rata-rata yang lebih besar dengan konsentrasi jembatan garam yang lainnya. Nilai CCV rata-rata yang dihasilkan pada konsentrasi jembatan garam tidak terlalu terlihat selisih tegangan yang cukup jauh. Konsentrasi jembatan garam keempat menunjukkan nilai CCV yang dihasilkan tidak stabil.

\subsection{Kuat Arus}

Data hasil penelitian diperoleh nilai kuat arus yang dihasilkan oleh elektroda $\mathrm{Cu}(\mathrm{Ag})-\mathrm{Zn}$ berbahan elektrolit air laut dapat dilihat pada Gambar 5. 


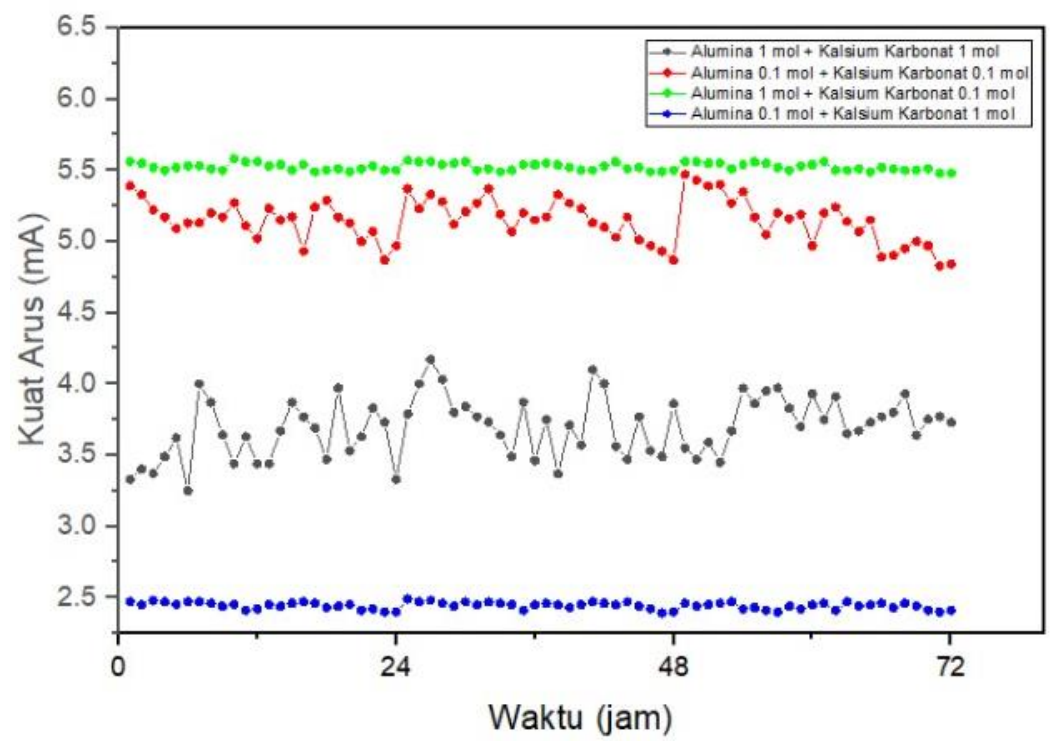

Gambar 5. Hasil pengukuran kuat arus

Gambar 5 menunjukkan hasil pengukuran kuat arus variasi konsentrasi jembatan garam pertama mengalami ketidakstabilan. Nilai kuat arus tertinggi yang didapatkan sebesar 4,33 mA. Variasi konsentrasi jembatan garam kedua pun nilai pengukuran yang dihasilkan tidak stabil. Nilai kuat arus pada jam pertama sebesar 5,39 mA dan nilai kuat arus pada jam ke-72 sebesar 4,84 mA. Penurunan nilai kuat arus pada jembatan garam kedua sebesar $0,55 \mathrm{~mA}$. Variasi konsentrasi jembatan garam ketiga memiliki nilai kuat arus yang besar dibandingkan dengan jembatan garam lain. Karena variasi konsentrasi yang digunakan untuk nilai alumina besar dan kalsium karbonat bernilai kecil (Parkash, 2016). Nilai hasil pengukuran yang diperoleh cukup stabil. Variasi konsentrasi jembatan garam keempat memiliki nilai kuat arus yang berbanding terbalik dengan jembatan garam ketiga. Nilai kuat arus yang didapatkan lebih kecil namun hasil pengukuran cukup stabil.

Tabel 3. Hasil pengukuran kuat arus

\begin{tabular}{cccc}
\hline Alumina $(\mathrm{mol})$ & Kalsium karbonat $(\mathrm{mol})$ & Rata-Rata $(\mathrm{mA})$ & Keterangan \\
\hline 1 & 1 & 3,697 & Tidak Stabil \\
0,1 & 0,1 & 5,148 & Tidak Stabil \\
1 & 0,1 & 5,523 & Stabil \\
0,1 & 1 & 2,443 & Stabil \\
\hline
\end{tabular}

Tabel 3 menunjukkan hasil pengukuran kuat arus. Berdasarkan hasil pengukuran tersebut, nilai kuat arus rata-rata pada konsentrasi jembatan garam keempat menunjukkan nilai yang kecil dibandingkan dengan konsentrasi jembatan garam lainnya. Perbedaan hasil pengukuran rata-rata kuat arus jembatan garam pertama dengan jembatan keempat cukup besar yaitu sebesar 3,08 mA.

\subsection{Perhitungan Hambatan Dalam dan Daya}

Berdasarkan nilai OCV, CCV dan I terhadap waktu dapat dilakukan perhitungan untuk mencari nilai hambatan dalam $\left(R_{\text {in }}\right)$ menggunakan persamaan (1) dan daya $(P)$ menggunakan persamaan (2). Adapun data $R_{\text {in }}$ tersebut ditampilkan dalam bentuk grafik yang dapat dilihat pada Tabel 4.

Tabel 4. Hasil perhitungan hambatan dalam

\begin{tabular}{ccc}
\hline Alumina $(\mathrm{mol})$ & Kalsium karbonat $(\mathrm{mol})$ & Rata-Rata $(\mathrm{kOhm})$ \\
\hline 1 & 1 & 0,352 \\
0,1 & 0,1 & 0,209 \\
1 & 0,1 & 0,236 \\
0,1 & 1 & 0,325 \\
\hline
\end{tabular}

Tabel 4 menunjukkan hasil perhitungan hambatan dalam. Hasil perhitungan tersebut menunjukkan bahwa konsentrasi jembatan garam pertama memiliki nilai hambatan dalam yang cukup besar. Selisih nilai rata-rata hambatan dalam pada setiap konsentrasi jembatan garam terlihat tidak terlalu jauh. Hasil perhitungan tersebut menunjukkan bahwa semakin besar konsentrasi jembatan garam kalsium karbonat maka semakin besar nilai hambatan dalam yang dihasilkan. 
Pauzi GA, Anwar S, Supriyanto A, dan Suciyati SW, 2021, Analisis Jembatan Garam Campuran Alumina dan Kalsium Karbonat pada Karakteristik Elektrik Pembangkit Listrik Sel Galvanis dengan Elektrolit Air Laut, Journal of Energy, Material, and Instrumentation Technology, Vol. 2, No. 4, 2021

Tabel 5. Hasil perhitungan daya

\begin{tabular}{ccc}
\hline Alumina $(\mathrm{mol})$ & Kalsium karbonat $(\mathrm{mol})$ & Rata-Rata $(\mathrm{mW})$ \\
\hline 1 & 1 & 9,057 \\
0,1 & 0,1 & 12,713 \\
1 & 0,1 & 15,001 \\
0,1 & 1 & 5,449 \\
\hline
\end{tabular}

Tabel 5 menunjukkan hasil perhitungan daya. Hasil perhitungan tersebut dapat kita ketahui bahwa nilai daya terkecil dihasilkan oleh konsentrasi jembatan garam keempat. Selisih nilai perhitungan rata-rata daya yang diperoleh dari setiap jembatan garam cukup besar. Nilai perhitungan rata-rata daya tertinggi sebesar $15,001 \mathrm{~mW}$, sedangkan nilai perhitungan rata-rata daya terendah sebesar 5,449 $\mathrm{mW}$. Selisih hasil perhitungan rata-rata data tertinggi dengan terendah adalah 9,552 $\mathrm{mW}$.

\subsection{Analisis Jembatan garam}

Pengukuran besarnya tegangan dan arus yang dihasilkan oleh sel volta ditunjukkan pada Tabel 6 dan tabel 7. Beban yang digunakan adalah 20 LED yang disusun secara seri dan dihubungkan pada sel volta. Pengukuran merupakan hasil rata-rata pengamatan tegangan dan arus tiap sel selama 72 jam dengan pengambilan data setiap 1 jam.

Tabel 6. Tegangan sel volta dengan berbagai jembatan garam selama 72 jam

\begin{tabular}{ccccc}
\hline \multirow{2}{*}{ Keterangan } & \multicolumn{4}{c}{ Variasi jembatan garam } \\
\cline { 2 - 5 } & $\begin{array}{c}\text { Alumina 1 mol }+ \\
\text { kalsium } \\
\text { karbonat 1 mol }\end{array}$ & $\begin{array}{c}\text { Alumina 0,1 mol + } \\
\text { kalsium karbonat } \\
0,1 \mathrm{~mol}\end{array}$ & $\begin{array}{c}\text { Alumina 1 mol + } \\
\text { kalsium karbonat } \\
0,1 \mathrm{~mol}\end{array}$ & $\begin{array}{c}\text { Alumina 0,1 mol + } \\
\text { kalsium karbonat } \\
1 \mathrm{~mol}\end{array}$ \\
\hline $\begin{array}{c}\text { Tegangan rata-rata } \\
\text { sel volta }\end{array}$ & 3,745 & 3,542 & 4,019 & 3,024 \\
Rata-rata tiap sel & 0,749 & 0,708 & 0,803 & 0,604 \\
\hline
\end{tabular}

Hasil pengukuran tegangan Tabel 6 merupakan pengukuran saat beban 20LED dilepaskan (tanpa beban). Tabel 6 menunjukkan bahwa tegangan rata-rata pada sel volta dengan variasi konsentrasi jembatan garam alumina $1 \mathrm{~mol}+$ kalsium karbonat 0,1 mol lebih besar dari sel volta dengan variasi konsentrasi jembatan garam lainnya. Pada tegangan rata-rata setiap sel pada seluruh variasi konsentrasi jembatan garam tidak terlihat selisih tegangan yang cukup besar. Namun tinjauan dengan hanya mengamati variabel tegangan tidak cukup tanpa melihat besarnya arus yang dihasilkan oleh sumber tegangan (sel volta). Pengukuran kuat arus yang mengalir pada beban seperti pada tabel 7.

Tabel 7. Pengukuran arus sel volta dengan berbagai jembatan garam selama 72 jam

\begin{tabular}{ccccc}
\hline \multirow{2}{*}{ Keterangan } & \multicolumn{4}{c}{ Variasi jembatan garam } \\
\cline { 2 - 5 } & $\begin{array}{c}\text { Alumina 1 mol + } \\
\text { kalsium } \\
\text { karbonat 1 mol }\end{array}$ & $\begin{array}{c}\text { Alumina 0,1 mol + } \\
\text { kalsium karbonat } \\
0,1 \mathrm{~mol}\end{array}$ & $\begin{array}{c}\text { Alumina 1 mol + } \\
\text { kalsium karbonat } \\
0,1 \mathrm{~mol}\end{array}$ & $\begin{array}{c}\text { Alumina 0,1 mol + } \\
\text { kalsium karbonat } \\
1 \mathrm{~mol}\end{array}$ \\
\hline $\begin{array}{c}\text { Rata-rata 24 jam } \\
\text { sel volta }\end{array}$ & 3,697 & 5,148 & 5,523 & 2,443 \\
Rata-rata tiap sel & 0,739 & 1,029 & 1,104 & 0,488 \\
\hline
\end{tabular}

Pada Tabel 7 menunjukkan hasil pengukuran arus sel volta dengan berbagai variasi konsentrasi jembatan garam selama 24 jam. Berdasarkan tabel pada variasi konsentrasi jembatan garam alumina 1 mol + kalsium karbonat 0,1 mol memiliki nilai arus rata-rata yang terbesar dengan variasi konsentrasi jembatan garam lainnya dengan nilai sebesar 5,523 mA. Sedangkan nilai arus rata-rata terkecil pada variasi konsentrasi jembatan garam alumina 0,1 mol + kalsium karbonat $1 \mathrm{~mol}$ sebesar 2,443 mA, hal ini menunjukkan bahwa terdapat hambatan dalam yang cukup tinggi. Konduktivitas yang kecil sangat berpengaruh pada besarnya arus dan daya yang dihasilkan oleh sel volta.

\section{Kesimpulan}

Berdasarkan analisis yang telah dilakukan, dapat disimpulkan bahwa semakin besar konsentrasi jembatan garam alumina maka akan semakin besar nilai tegangan yang dihasilkan. Nilai hambatan dalam akan semakin besar apabila konsentrasi jembatan kalsium karbonat memiliki nilai hambatan dalam yang besar. 


\section{Daftar Pustaka}

Akbar, T. N., Kirom, M. R., \& Indra, R. F. (2017). Analisis Pengaruh Material Logam Sebagai Elektroda Microbal Fuel Cell Terhadap Produksi Energi Listrik. e-Proceeding of Engineering, 04(02), 2123-2138.

Arizal, F., Hasbi, M., \& Kadir, A. (2017). Pengaruh Kadar Garam Terhadap Daya yang Dihasilkan Pembangkit Listrik Tenaga Air Garam Sebagai Energi Alternatif Terbarukan. In JENTHALPHY-Jurnal Ilmiah Mahasiswa Teknik Mesin, 02(01), 1-5.

Crus, R. O., Avila, E., Mejia, E., Perez, T., Contreras, A. \& Martinez, R. G. (2017). In situ Corrosion Study of Copper and Copper-Alloys Exposed to Natural Seawater of the Veracruz Port (Gulf of Mexico). International Journal of Electrochemical Science, 12(01), 3133-3152.

Haq, S. Z. N., Kurniawan, E. \& Ramdhani, M. (2018). Analisis Pembangkit Elektrik Menggunakan Media Air Garam Sebagai Larutan Elektrolit. e-Proceeding of Engineering, 05(03), 3823-3830.

Kementerian Energi dan Sumber Daya Mineral. (2018). Materi Paparan Kementerian Energi dan Sumber Daya Mineral Rapat Koordinasi Infrastruktur Ketenagalistrikan. Kementerian Energi dan Sumber Daya Mineral. Bali.

Kholiq, I. (2015). Pemanfaatan Energi Alternatif Sebagai Energi Terbarukan untuk Mendukung Subtitusi BBM. Jurnal IPTEK, 19(02), 75-91.

Khormali, A., Petrakov, D. G, \& Moghaddam, R. N. (2017). Study of Adzorption/Desorption Properties of a New Scale Inhibitor Package to Prevent Calcium Carbonate Formation During Water Injection in Oil Reservoirs. Journal of Petroleum Science and Engineering, 153(01), 257-267.

Parkash, A. (2016). Characterization pf Generated Voltage, Power and Power Density from Cow Dung Using Double Chambered Microbial Fuel Cell. Journal of Physical Chemistry and Biophysics, 6(01), ISSN: 2161-0398.

Pauzi, G. A., Hudaya, E., Supriyanto, A., Warsito \& Surtono, A. (2016). Analisis Uji Karakteristik Elektrik Air Laut Sebagai Sumber Energi Listrik Terbarukan. Prosiding Seminar Nasional Sains Matematika Informatika dan Aplikasinya IV Fakultas MIPA, 04, ISSN: 2086-2342.

Pauzi, G. A., Riski, K. C., Suciyati, S. W., Junaidi, Surtono, A., Supriyanto, A., \& Warsito. (2018a). Improvement of Characteristics of Electrochemical Cells made from Seawater Using Electroplating Method of $\mathrm{Cu}(\mathrm{Ag})-\mathrm{Zn}$ Electroda as Renewable Energy Source. Proceeding $2^{\text {nd }}$ International Conference Applied Sciences Mathematics and Informatics 2018. Bandar Lampung. Indonesia.

Pauzi, G. A., Arwaditha, R. K., Supriyanto, A., Suciyati, S. W., Surtono, A., Junaidi \& Warsito. (2018b). Desain dan Realisasi Akumulator Elektrolit Air Laut dengan Penambahan Sodium Bicarbonate $\left(\mathrm{NaHCO}_{3}\right)$ sebagai Sumber Energi Alternatif. Jurnal Fisika, 08(2), 78-88.

Prastuti, O. P., (2017). Pengaruh Komposisi Air Laut dan Pasir Laut Sebagai Sumber Energi Listrik. Jurnal Teknik Kimia dan Lingkungan, 01(01), 35-41.

Pratisto, Y., Prastowo, H., \& Soemartoyo, W. A. (2014). Prototipe Pembangkit Listrik Tenaga Air Memanfaatkan Teknologi Sistem Pipa Kapiler. Jurnal Teknik Pomits, 3(01), 99-103.

Votava, J. (2013). Corrosion Resistance of Zinc-Based System in $\mathrm{NaCl}$ Environment. Acta Universitas Agriculturae et Silviculturae Mendelianae Brunensis, 61(05), 1487-1495.

Wibowo, A. (2016). Analisis Sifat Korosi Galvanik Berbagai Plat Logam di Laboratorium Metalurgi Politeknik Negeri Batam. Jurnal Intergrasi, 08(02), 144-147. 